\title{
Nursing as Accommodated Care: A Contribution to the Phenomenology of Care. Appeal, Concern, Volition, Practice
}

\author{
Björn Freter
}

\section{Introduction}

In this investigation, I will attempt to pinpoint the connection between nursing und care. On the one hand, I wish to understand the extent to which nursing represents a genuine normative practice, while on the other hand establishing how the normativity of this practice actually comes about. My hypothesis is as follows: nursing, ${ }^{1}$ as I suspect and intend to investigate here, is to be understood as accommodated care.

It is not my intention to produce a normative draft determining what qualifies as caring or nursing and what does not. In order to verify the validity of this hypothesis, I first intend to develop a phenomenology of care.

\footnotetext{
I would like to thank Dinah Laubisch (Berlin), Kerry Jago (Bonn), Karoline Pietsch (Berlin), Annekatrin Skeide (Bremen) and Joachim Boldt (Freiburg) for helpful comments on first drafts of this text. I also wish to thank the Department of Neurology at the Schlosspark-Klinik (Berlin) for the opportunity to present and discuss a preliminary version of this work as part of an internal training workshop.
}

\section{B. Freter $(\bowtie)$}

Independent Scholar, Berlin, Germany 
This phenomenological approach is, as far as I can tell, especially suited to an examination of caring and thus of nursing. I must first take seriously the normative practices that I encounter when somebody nurses; I must precisely describe what actually happens in this situation. My phenomenological approach aims primarily at a description of the phenomenon of care. Emphasis is placed first and foremost on the phenomenon, which is why the approach is to be characterised as phenomenological. Only once I have such a description, only once I have such a phenomenology, so to speak, can I begin-in a much later step- to comment on these practices from a normative standpoint.

This phenomenological approach will be of key significance for the interpretation of care as an existential pattern of my method of dealing with reality. This pattern is to be understood in a proto-ethical manner, and not, as is often the case in care ethics, as something that is in itself, in a normative sense, good.

After the phenomenological beginning, I will attempt to apply the phenomenology of care to nursing.

\section{The General Phenomenology of Care}

Care is always initiated by an appeal. Something appeals to us-perhaps purely coincidentally. I then allow this appeal to become a matter of my concern. In accordance with this concern, I develop a volition: I want that which promotes the thriving — even to the smallest extent — of that which has appealed to us, that which concerns us, regardless of how I may establish what that entails. Eventually I take practical action. This connection is what I refer to as care. ${ }^{2}$

Perhaps I hold on to the object of my care in the future and the care becomes love (Freter 2016, pp. 351-363), or perhaps, as the case may also be, I immediately release the source of the appeal from my care again and send it on its way.

In the following section, I will attempt to show how this basic phenomenological structure can indeed be derived from a famous literary account, namely the "Gospel According to Luke", in the so-called Parable of the Good Samaritan. 
I will examine this parable as a literary narrative and interpret it without regard to its theological and polemical content. I will concentrate solely on the phenomenon of care, which appears in the text, somewhat inadvertently, as a by no means exclusively Christian phenomenon, but rather as a human phenomenon in general.

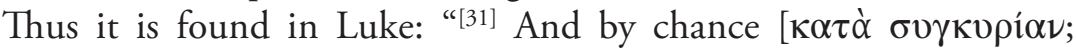
Accidit autem]" (Luke 10, 31)-here there is the moment of coincidence- "there came down a certain priest that way: and when he saw

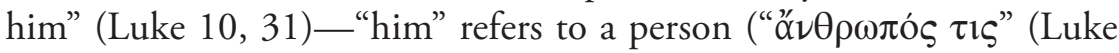

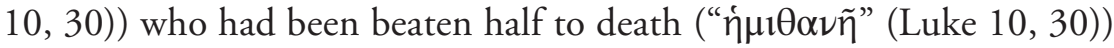
by robbers-, so when he "saw [i $\delta \omega \dot{\nu} \nu$. viso] him, he passed by on the other side [ $\alpha \dot{\nu} \tau \imath \pi \alpha \rho \tilde{\eta} \lambda \theta \varepsilon \nu$. praeterivit]" (Luke 10, 31). The priest saw"i $\delta \dot{\omega} \nu$ " - the person in need, but he did not accept the appeal, for whatever reason (Zimmermann 2007, p. 544). ${ }^{3}$ He avoided the possible appeal, he does not want, in the literal Greek translation, to go too close (cf. Wolter 2008, p. 396): " $\alpha \nu \tau \imath \pi \alpha \rho \tilde{\eta} \lambda \theta \varepsilon \nu$ ", which is made up of $\alpha \nu \tau 1$ (not)— $-\pi \alpha \rho$ (near) - $\check{\varepsilon} \rho \chi 0 \mu \alpha 1$ (go). This is repeated with a Levite: "[32] And likewise a Levite, when he was at the place, came and looked on him [i $\delta \dot{\omega} \nu$. videret] and passed by on the other side [ $\alpha \nu \tau 1 \pi \alpha \rho \tilde{\eta} \lambda \theta \varepsilon \nu$. praetereo]" (Luke 10, 32).

Now the Samaritan appears:

${ }^{[33]}$ But a certain Samaritan, as he journeyed, came where he was [ $\tilde{\eta} \lambda \theta \varepsilon v$ $\kappa \alpha \tau$ ' $\alpha \dot{\tau} \tau \dot{o} \nu$. venit secus eum]; and when he saw him [ỉं $\dot{\omega} \nu$. videns], he had

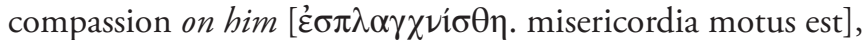

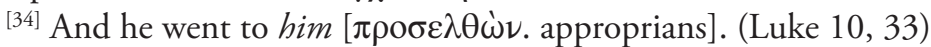

The Samaritan does not pass by, but goes to the helpless man" $\pi \rho \circ \sigma \varepsilon \lambda \theta \dot{\omega} \nu$ " - and is "moved within", $\sigma \pi \lambda \alpha \gamma \chi \nu i \zeta o \mu \alpha 1$, as the original Greek puts it. He was touched, in accordance with the etymology of this verb, in the "innards", in the $\sigma \pi \lambda \alpha \dot{\alpha} \chi \nu \alpha \alpha$ (cf. Frisk 1972, pp. 769 ff.; Zimmermann 2007, p. 539).

The Samaritan, for whatever reason this was possible for him, allowed himself to be appealed to. He makes the injured man his concern and can come near ( $\pi \rho \circ \sigma \varepsilon \dot{\varepsilon} \chi 0 \mu \alpha \mathrm{l}$ ) him. To the injured man, to whom he had just now been a stranger-just a "ő $\nu \theta \rho \omega \pi$ ó $\tau 1 \varsigma$ ”-, the Samaritan 
becomes the closest ( $\pi \lambda \eta \sigma$ íos, proximus (cf. Luke 10, 29 and 10, 36 ff.)), and the beaten man simultaneously becomes his closest (cf. Wolter 2008, p. 391).

The Samaritan does not want the injured man to continue to be in the state in which he has been: He does not want that which is. The concern has been compressed, has been turned into volition, substantiated to a volition: to a volition for the sake of the concern. The condition of the injured man ought to improve. It ought, therefore, to be different. It ought not to be as it is. This seems to us to be of decisive importance. The Samaritan takes issue with the situation as he finds it. He sets his will against that which is. This appears to be one important source of the ought: when I posit my will, as it arises from my being, against that which is, when I say: it ought not to be so, but rather how I, for the sake of the other person, want it to be. And this will for the sake of another, I suspect, is a preliminary form of the ought.

Thus the Samaritan takes practical action, and as the story continues, he "bound up his wounds, pouring in oil and wine, and set him on his own beast, and brought him to an inn, and took care of him [ $\kappa \alpha i$

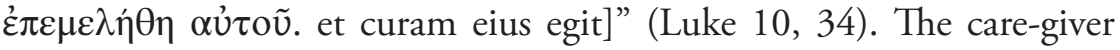
then releases the nameless man from his care (Zimmermann and Zimmermann 2003, pp. 54-58): " ${ }^{[35]}$ And on the morrow when he departed, he took out two pence, and gave them to the host, and said

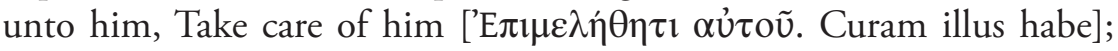
and whatsoever thou spendest more, when I come again, I will repay thee" (Luke 10, 35). What may have happened after that is not mentioned, but it is not important for these purposes.

As I stated, the Samaritan does not want the continued suffering of the nameless man. I can form such a will-I now move away from the connection to the parable-because I want to address the concern of the person who has appealed to us: I place my will in the service of their concern. This will is the central element of the story.

The will is then transformed. This will, which I bring forth in the course of my care, encounters me once again — seemingly foreign, seemingly having become independent_ — as a demand made to myself.

This ought is by no means to be understood universally. With the help of this "origin story" of the ought, I indeed intend to establish that 
the ought, at least in one of its forms, at least when close to its very first formation, has unfolded and developed out of my own will: will is encountered again as an ought that is addressed to me. This ought, however, is primarily valid for me, although I may also wish it to be valid for others as well. But the most important point here is that first and foremost, I subject myself to an ought that, through the transformation from "I want" to "it should be", has acquired a quasi-objective character for us.

In the course of the care, through the practical actualisation of my being, I have therefore set to work an ought_-as short-lived as this ought may perhaps be - to which I have subsequently committed myself. In the course of the care, therefore, normativity itself, the ought-to-be, has become reality: for the sake of the concern, I have brought forth a will, into the service of which I have then placed myself. And I have done this as if this will were no longer my own. This will has seemingly become a will that is addressed to us, meaning: it has become a demand, it has become an ought.

I thus understand an ought as a will that is addressed to us. The ought - at least in this form — can be grasped as something that was once my own volition, a volition that has quasi-extricated itself from us, has transcended us, in order then to encounter us once more as this extricated, transcended volition, addressing us with this will (cf. Freter 2016, pp. 361-363). ${ }^{4}$

I have posited with the ought a fact, or to be more precise, an existential fact (cf. Freter 2016, pp. 52-59). I have created something new, something that was not there before, a normative entity. And I have subsequently committed myself to this positing-which is entirely my own but at the same time entirely foreign. I can thus newly define care altogether: caring means to believe that one is subject to an ought.

At this point I must point out that the person who cares is by no means restricted to the notion of altruism. It is not to be assumed that somebody who cares has only the well-being of the other person in mind. I in fact suspect that that which I understand as evil actually arises from precisely this pattern of care which I have described here, namely when I only allow myself to be appealed to by myself and place myself exclusively 
in the service of caring for myself, that is when I care excessively only for myself. 5

But let us return to the topic at hand: care, as I wish to pinpoint once again, is realised through the quartet of appeal, concern, volition and practice. The care-giver wants that to be which promotes the care for the sake of the concern, and in following this takes practical action.

\section{Appeal in the Nursing Context}

Care is initiated, as I have found, by an appeal, an appeal which may be directed purely coincidentally towards us. I also find an appeal at the initiation of nursing. However, this appeal has been stripped of any coincidence, and, moreover, at the initiation of nursing, I find the will to allow oneself to be appealed to, the will to encounter the person who wishes to appeal, indeed who must appeal. Nursing thus begins with the nursing care-giver placing him/herself in a position in which he or she can and may be found and approached in this role (cf. Martin et al. 2015, p. 635$).^{6}$

Within this fact, I believe, is contained a first fundamental principle of nursing. The Principle of the Appeal states: the nursing care-giver wishes to communicate his or her approachability — in a certain environment at a certain time, and not any longer once these limits of place and time are exceeded. The nursing care-giver wishes to be found in precisely this role (cf. Eley et al. 2010, pp. 10 ff.; 2012, p. 15537; Price 2009, p. 16 ${ }^{8}$; Smith and Godfrey 2002; Smith et al. 2013).

I am speaking about what the nursing care-giver "wishes", not what he or she "should" do, for I am not concerned with creating instructions for those who do not wish to nurse, but rather with attempting to understand the (self-produced) ought, the demands to which the person who wishes to nurse-tacitly-subjects him/herself. Subjecting him/herself to these demands is what allows the nursing care-giver to be recognised as such-even when these demands can sometimes not be met, as may be the case in periods of tiredness, overwork or stress. ${ }^{9}$ 


\section{Normative Uncertainties}

In the course of my considerations on the appeal in the nursing context, I have made two claims. Firstly: nursing is a form of care. As I have shown though, the care for the well-being of the patient becomes an obligation for the care-giver. This means that secondly: the nursing care-giver acts first and foremost normatively (cf. Bishop and Scudder 1991, p. 18 ${ }^{10}$; Smith and Godfrey 2002, p. $302^{11}$ ), as he or she works towards realising that which ought to be for the sake of the patient, that is: he or she aims to create, maintain, improve or restore a patient's well-being.

Because this is the purpose, that is realising that which ought to be for the sake of the patient, ethical problems will necessarily arise while nursing. This is due to the fact that the determination of that which ought to be, that which ought to be for the sake of the patient, is - as countless social debates have shown—something which must be repeatedly determined anew. This, however, is the decisive reason to nobilitate nursing as an originary normative practice: the nursing care-giver places him/herselfwhether fully aware of this or not-personally as a care-giver (cf. Smith and Godfrey 2002) into the highly contentious field of normative fluctuation - both individual and of society as a whole. This service, it seems to us, does not yet receive the social acknowledgement it deserves (cf. Lachmann 2012, p. 1142; Swanson 1993, p. 354).

I have to accept that nursing means exposing oneself to normative uncertainties. Here, as in life in general, there is no ultimate protection from the constant threat of the return of normative obscurity: the wellbeing of the patient is indeed a very murky subject. The uncertainty of this stipulation, even though it is and must remain an undisputed guideline, shows us that it is of paramount importance-from a normative perspective, which is all that concerns us here-to provide support to care-givers in making decisions, rather than simply handing down instruction manuals and rules and so on that-supposedly-list what is right and wrong. ${ }^{13}$

Let us imagine a patient with diabetes mellitus who refuses to curtail his consumption of sweets. It is indeed not unequivocally clear, provided I do not allow myself to be drawn into some form of reductionism, what is to be done in this case. It is not of genuine assistance simply to inform 
the patient about the course of diabetic illnesses when foodstuffs containing sugar are consumed-although such knowledge is without a doubt necessary for a serious confrontation with the problem. Certainly from such a (reductionist) perspective, it is absolutely necessary to remove access to the foodstuffs in question; however a care-giver may manage this. But, the patient is not simply diabetes mellitus, he is not simply this one disease. He is someone who has this disease: he is someone who is also much more than this, namely his entire body, and not only this body inasmuch as diabetes mellitus can be observed within it. He is someone who also has so much more, for example an attitude regarding his own illness. My patient could - with good reason-insist upon having a short, enjoyable life rather than a long one marked by deprivation

It cannot be clearly decided, if I am to remain within this simple dichotomy, whether the shorter or the longer life is objectively preferable. Objectivity cannot be achieved here. One can argue with good reason in favour of the one option, and with equally good reason in favour of the other. In this situation, the care-giver, despite recourse to supervision and the necessary specialist knowledge and so on, is nevertheless faced with a very personal normative challenge. Furthermore, and this fact must be given recognition, he or she must be given leeway for this decision appropriate to the vagueness of the issue: the solution is not to prescribe one course of action or another, to demand either forced withdrawal or an ignoring of the consumption. It must be possible for the care-giver to make a decision as to the course of action, to create, maintain, improve or restore the patient's well-being.

I have stated firstly: nursing is a form of care. This means secondly: nursing is a form of care. It is one particular form of care, or to be more precise: nursing is a particular normative human reaction to the notorious frailty of one's neighbour.

Nursing does not accept the (actuated) reality, as it is, as the best possible scenario, but rather attempts-healing, soothing, assisting-to make the best possible scenario (possibilitas) — I are painfully aware of the darkness surrounding this term-become reality (actualitas). This best possible scenario, always in terms of the patient's needs, can materialise in divergent ways: perhaps in recovery, perhaps in a peaceful death, perhaps in something else. 
Because nursing is concentrated in this way, because nursing is adapted in this way to a certain domain - even if that is difficult to define-I can speak of nursing as accommodated care. To nurse, I can say, is to care in a very specific way, in an accommodated fashion. ${ }^{14}$

\section{Concern, Volition and Practice in the Nursing Context}

If nursing is to be understood as care, it is thus to be presumed that the quaternary phenomenology of care- that is not only the appeal, as I have attempted to show, but also concern, volition and practice-is similarly reflected in nursing. ${ }^{15}$ I now wish to conclude my investigation with a brief look at where the reflections of concern, volition and practice in the context of nursing can be found.

Just as the nursing care-giver wishes to be appealed to, he or she subsequently wishes every appeal to become his or her concern. The care accommodated to become nursing is concerned with that which has appealed to it. The Principle of Concern states: the nursing caregiver wishes to be concerned with that which was allowed to make the appeal. An appeal is not only noted, but also made a cause for concern.

This cause for concern manifests itself in the direct volition to do something for the sake of the source of the appeal. The Principle of Volition and Practice in Nursing thus states: the nursing care-giver wishes to take practical action for the sake of the concern.

\section{Notes}

1. When, in the following discourse, we speak of nursing, we are referring not to the profession of nursing in the narrow sense, but rather to medical practice in its entirety. A compact overview of widespread nursing theories in the narrow sense (Virginia Henderson, Dorothea Orem, Nancy Roper, Monika Krohwinkel, Erwin Böhm) can be found in Lauf (2013, pp. 61-71). 
2. Joan Tronto has provided a somewhat similar representation from a feminist-political perspective (cf. Tronto 1993). There are, however, several differences to our approach, particularly the fact that for Tronto, compassion with the other person and the understanding of care as a collective process play an important role. This is not the case in our proto-ethical approach, which is why we will not go into Tronto's work in more detail here. A critical study of the fundamental aspects of Tronto's approach is provided by Edwards (2009, pp. 233-238), an overview to different concepts of care (including Tronto's approach) is provided by Kohlen and Kumbruck (2008).

3. Carl Amery undertook the interesting exercise of allowing the "minor characters" of the parable (the priest, the Levite, the innkeeper and even the leader of the robbers) to express themselves and to explain their respective actions (cf. Amery 1973).

4. It seems, as we wish to note only in passing, to be immaterial for the significance of the ought whether it was created as an existential factum, as we claim here, or whether it encountered me as a facticity.

5. Protest against the tendency of caring ethics to interpret care fundamentally as something essentially good — an idea brought forth primarily by Carol Gilligan and Nel Noddings— has also arisen within the field of nursing studies, cf. for example Allmark (1995); Bradshaw (1996); Edwards (2009, pp. $232 \mathrm{ff}$ ).

6. "Care is an affectively charged and selective mode of attention that action, affection, or concern at something, and in effect, it draws attention away from other things. In practice, a person who cares is one who has already chosen an object to care about. Consider, however, that prior to securing a thing to care for, a person must have the capacity or willingness to respond, to be called into action, to be hailed by that object or phenomenon. In short, a person who cares must first be willing and available to be moved by this other."

7. "[T]here was notable consistency between students and nurses in reasons for entering nursing affected by neither age nor level of experience. This finding along with high levels of innate personal traits that are conducive to a caring and cooperative nature suggests that individuals are drawn to nursing for similar reasons. There was a general consensus by participants that 'all sorts of personalities make a good nurse' and the dominant trait of a good nurse is that 'desire to care'." 
8. "Despite individual differences in perspectives of nurses and nursing, most studies [analysed in this meta-study] identified that nurses held some construction of an 'ideal' nurse that usually focused on caring."

9. The problem of care-givers not being able to meet the necessary demands (e.g. due to a high workload) is mentioned repeatedly in empirical investigations (cf. Price 2009, pp. 16 ff. (on the paradox of caring); Eley et al. 2010, 2012).

10. "Nursing is a practice with an inherent moral sense."

11. "Nursing is by nature a moral endeavour."

12. "Care can be considered simply an ethical task and thus a burden of one more thing to do, or it can be considered a commitment to attending to and becoming enthusiastically involved in the patient's needs."

13. See the contribution by Opgenhaffen in this volume (Chapter "Regulation as an Obstacle to Care? A Care-Ethical Evaluation of the Regulation on the Use of Seclusion Cells in Psychiatric Care in Flanders (Belgium)").

14. There can, of course, also be other accommodations of care, but that is not of interest to me here.

15. Moreover, if nursing is recognised as care, it seems necessary to support and encourage it as care, and consequently to support and encourage the realisation of the constitutive moments of that care-appeal, concern, volition and practice.

\section{References}

\section{The English text of the Gospel according to Luke is quoted from:}

Carroll, R., \& Prickett, S. (Eds.). (2008). The Bible. Authorized King James Version. Oxford: Oxford University Press.

\section{The Greek and Latin texts from the Gospel according to Luke are quoted from:}

Nestle, E., \& Aland, K. (1984). Novum Testamentum. Graece et Latine (26th ed.). Stuttgart: Deutsche Bibelgesellschaft. 
Allmark, P. (1995). Can There Be an Ethics of Care? Journal of Medical Ethics, 21, 19-24.

Amery, C. (1973). Nebenfiguren. In W. Jens (Ed.), Der barmherzige Samariter (pp. 19-28). Stuttgart: Kreuz.

Bishop, A. H., \& Scudder, J. R. (1991). Nursing. The Practice of Caring. New York: National League for Nursing Press.

Bradshaw, A. (1996). Yes! There Is an Ethics of Care: An Answer for Peter Allmark. Journal of Medical Ethics, 22, 8-15.

Edwards, S. (2009). Three Versions of an Ethics of Care. Nursing Philosophy, 10(4), 231-240.

Eley, R., Eley, D., \& Rogers-Clark, C. (2010). Reasons for Entering and Leaving Nursing: An Australian Regional Study. Australian Journal of Advanced Nursing, 28(1), 6-13.

Eley, D., Eley, R., Bertollo, M., \& Rogers-Clark, C. (2012). Why Did I Become a Nurse? Personality Traits and Reasons for Entering Nursing. Journal of Advanced Nursing, 68(7), 1546-1555.

Freter, B. (2016). Wirklichkeit und existentiale Praxis. Vorarbeiten zu einer Phänomenologie der Normativität entwickelt an narrativen Texten der altgriechischen, neutestamentlichen, mittelhochdeutschen und klassischen deutschen Literatur. Berlin: Lit-Verlag.

Frisk, H. (1972). Griechisches etymologisches Wörterbuch. Band 2. Heidelberg: Carl Winter.

Kohlen, H., \& Kumbruck, C. (2008). Care-(Ethik) und das Ethos fürsorglicher Praxis (Literaturstudie). artec-paper 151. Retrieved March 22, 2016, from http://nbn-resolving.de/urn:nbn:de:0168-ssoar-219593

Lachman, V. D. (2012). Applying the Ethics of Care to Your Nursing Practice. Ethics, Law and Policy, 21, 112-116.

Lauf, U. (2013). Berufskunde. In B. Hein (Ed.), Altenpflege konkret. Pflegetheorie und-praxis (pp. 1-93). Urban \& Fischer: München.

Martin, A., Myers, N., \& Viseu, A. (2015). The Politics of Care in Technoscience. Social Studies of Science, 45, 625-641.

Price, S. L. (2009). Becoming a Nurse: A Meta-Study of Early Professional Socialization and Career Choice in Nursing. Journal of Advanced Nursing, 65(1), 11-19.

Smith, K. V., \& Godfrey, N. S. (2002). Being a Good Nurse and Doing the Right Thing: A Qualitative Study. Nursing Ethics, 9(3), 301-312.

Smith, R., Lagarde, M., Blaauw, D., Goodman, C., English, M., Mullei, K., Pagaiya, N., Tangcharoensathien, V., Erasmus, E., \& Hanson, K. (2013). 
Appealing to Altruism: An Alternative Strategy to Address the Health Workforce Crisis in Developing Countries? Journal of Public Health, 35(1), $164-170$.

Swanson, K. M. (1993). Nursing as Informed Caring for the Well-Being of Others. Image: The Journal of Nursing Scholarship, 25(4), 352-357.

Tronto, J. C. (1993). Moral Boundaries. A Political Argument for an Ethic of Care. New York: Routledge.

Wolter, M. (2008). Das Lukasevangelium. Tübingen: Mohr Siebeck. Zimmermann, R. (2007). Berührende Liebe (Der barmherzige Samariter) Lk 10,30-35. In R. Zimmermann (Ed.), Kompendium der Gleichnisse Jesu (pp. 538-555). Darmstadt: Wissenschaftliche Buchgesellschaft.

Zimmermann, R., \& Zimmermann, M. (2003). Der barmherzige Wirt. Das, Samaritergleichnis' (Lk 10,25-37) und die Diakonie. In A. Götzelmann (Ed.), Diakonische Kirche - Anstöße zur Gemeindeentwicklung und Kirchenreform. Festschrift für Theodor Strohm zum 70. Geburtstag (pp. 44-58). Heidelberg: Winter.

Open Access This chapter is licensed under the terms of the Creative Commons Attribution 4.0 International License (http://creativecommons.org/licenses/ by/4.0/), which permits use, sharing, adaptation, distribution and reproduction in any medium or format, as long as you give appropriate credit to the original author(s) and the source, provide a link to the Creative Commons license and indicate if changes were made.

The images or other third party material in this chapter are included in the chapter's Creative Commons license, unless indicated otherwise in a credit line to the material. If material is not included in the chapter's Creative Commons license and your intended use is not permitted by statutory regulation or exceeds the permitted use, you will need to obtain permission directly from the copyright holder.

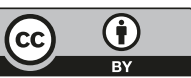

